\title{
A review of prognostic factors in early-stage carcinoma of the cervix (FIGO I B and II A) and implications for treatment strategy
}

\author{
P.F.J. van Bommel ${ }^{1}$, A.C.M. van Lindert ${ }^{1}$, H.C.L.V. Kock ${ }^{2}$, W.H. Leers ${ }^{3}$ \\ and J.P. Neijt ${ }^{1}$ \\ ' Departments of Gynecology and Medical Oncology, University Hospital, Utrecht, The Netherlands, \\ ${ }^{2}$ Department of Gynecology, Maria Ziekenhuis, Tilburg, The Netherlands, \\ and ${ }^{3}$ Dr Bernard Verbeeten Institute, Tilburg, The Netherlands
}

Accepted for publication 30 March 1987

\section{Summary}

Several prognostic factors in stages I B and II A cervical carcinoma have been widely studied to define groups of patients with a poor prognosis. Most of these factors are interrelated. The characteristics which should be regarded as main factors have not yet been defined, because the studies reported were based on mainly retrospective and non-randomized analysis. Reviewing the literature, lymph node metastasis, differentiation grade, tumor size, parametrial extension, lymphblood vessel invasion and cervical invasion seem to be prognostically important factors, which suggests that the subdivision of patients according to the FIGO classification alone is inaccurate. It seems useful to define subgroups of patients according to tumor characteristics, determined after surgical treatment and accurate histologic examination of the surgical specimen. Patients with one or more of these tumor features need additional treatment to improve survival. The current treatment modalities, such as postoperative radiotherapy, have not been thoroughly evaluated, but doubt exists as to their efficacy. Data in the literature suggest that particularly patients with para-aortic or multiple pelvic lymph node metastasis $(>3)$ have already developed distant metastases at the time of primary treatment and therefore need adjuvant systemic therapy. Patients with tumors larger than $4 \mathrm{~cm}$ in diameter, differentiation grade III, lymph-blood vessel invasion or cervical invasion (of more than 70\%) seem to have high recurrence rates at both pelvic and distant sites, indicating that there is also a need for better pelvic control.

Carcinoma, early-stage; Prognostic factor; Improved survival

Correspondence: A.C.M. van Lindert, Department of Gynecology, University Hospital, Catherijnesingel 101, Utrecht, The Netherlands. 


\section{Introduction}

Early-stage carcinoma of the cervix is associated with a good prognosis. Five-year survival rates of stages I B and II A are 80-90\% and 70-80\% respectively. In several large series, stages I B and II A have been evaluated together and 5-year survival rates of approximately $80 \%$ were reported. Patients are staged by the FIGO clinical classification. Stage I B and II A, in which there is no clinical infiltration of the parametria, can both be treated by either surgical or radiation therapy. The results obtained using these methods are comparable, there being no difference in morbidity and mortality $[16,36,39,47,90,97]$.

Still, about $20 \%$ of stage I B or II A patients die of cervical cancer and this has not changed in the past two decades. Several observations have suggested that treatment failure in this $20 \%$ may be attributed to the inadequacy of localized therapy when certain morphologic and histologic tumor features exist. The problem for the oncologist is to define these subsets of patients and seek more appropriate treatment modalities.

This paper reviews the prognostic factors which have been identified in early-stage carcinoma and discusses possible modifications of treatment for improving survival.

\section{Prognostic factors}

\section{Lymph node metastases}

Involvement of lymph nodes is probably one of the most important prognostic factors. The incidence of positive pelvic lymph nodes reported in the medical literature in stage I B and II A varied between 4 and 34\%, with a mean of 17\%. Much lower incidences of common iliac and para-aortic lymph node involvement, $3 \%$ and $5 \%$ respectively, have been found in these patient groups (Table I).

Analysis of recurrence sites demonstrated a slightly higher incidence of distant recurrence, with or without local recurrence when pelvic nodes were involved, namely $27 \%$ versus $16 \%$ local recurrences. In patients with positive para-aortic lymph nodes there is a high incidence (44\%) of distant recurrence, with or without local recurrence (Table II).

Patients with pelvic lymph node metastases had 5-year survival rates as low as $38 \%$ and as high as $62 \%$. In general, there is a fall in overall 5-year survival rate of approximately $50 \%$ when pelvic lymph nodes are involved (Table III). The number and degree of involvement of positive nodes have an additional detrimental influence on prognosis $[30,47,65,127]$. Inoue et al. [64] reported a 5-year survival of only $22 \%$ of 9 patients with more than 3 positive pelvic lymph nodes. A 5 -year survival rate of $31 \%$ was found by Pilleron et al. [109] in 26 patients with more than $20 \%$ of the lymph nodes removed positive. Unfortunately, there has been little documented about survival rates of early-stage patients with common iliac or para-aortic node metastases. Pilleron et al. [109] noted a 5-year survival rate of only $16 \%$ of patients with positive common iliac nodes in stages I and II. In advanced stages, 5-year survival rates of patients with para-aortic disease ranging from 16 to $32 \%$ have been described, illustrating the bleak prognosis $[3,11,63,112,115]$. 
TABLE I

Incidence of lymph node metastasis according to the highest level in stage I B and/or II A (FIGO)

\begin{tabular}{|c|c|c|c|}
\hline \multirow[t]{2}{*}{ Site } & \multicolumn{2}{|c|}{ Number of patients ${ }^{a}$} & \multirow[t]{2}{*}{ References } \\
\hline & $\overline{\text { Total }}$ & Positive nodes & \\
\hline \multirow[t]{16}{*}{ Pelvic } & 70 & $3(4)$ & 62 \\
\hline & 195 & $18(9)$ & 2 \\
\hline & 194 & $19(10)$ & 61 \\
\hline & 108 & $11(10)$ & 79 \\
\hline & 362 & $47(13)$ & 64 \\
\hline & 139 & $20(14)$ & 16 \\
\hline & 418 & $62(15)$ & 47 \\
\hline & 124 & $22(18)$ & 19 \\
\hline & 98 & $19(19)$ & 30 \\
\hline & 363 & $73(20)$ & 70 \\
\hline & 193 & $42(22)$ & 127 \\
\hline & 143 & $35(24)$ & 76 \\
\hline & 293 & $71(24)$ & 71 \\
\hline & 145 & $39(27)$ & 110 \\
\hline & 63 & $19(30)$ & 89 \\
\hline & 73 & $25(34)$ & 24 \\
\hline \multirow[t]{5}{*}{ Common iliac } & 363 & $8(2)$ & 70 \\
\hline & 193 & $4(2)$ & 127 \\
\hline & 98 & $3(3)$ & 30 \\
\hline & 202 & $5(3)$ & 60 \\
\hline & 293 & $20(7)$ & 71 \\
\hline \multirow[t]{7}{*}{ Para-aortic } & 98 & $3(3)$ & 30 \\
\hline & 140 & $6(4)$ & 63 \\
\hline & 254 & 9 (4) & 99 \\
\hline & 171 & $9(5)$ & 47 \\
\hline & 143 & $8(6)$ & 76 \\
\hline & 183 & $11(6)$ & 11 \\
\hline & 51 & $5(10)$ & 8 \\
\hline
\end{tabular}

${ }^{\text {a }}$ Figures in parenthesis denote percentages.

\section{Histology: cell differentiation and cell type}

The relationship between grade of cell differentiation of cervical cancer and survival has been the subject of numerous publications. In some studies tumors were subdivided into four grades of differentiation according to Broders [88,133]. Recent investigations distinguished three grades of differentiation, in which grades three and four are combined. Several authors reported a significantly better 5-year survival rate with well-differentiated lesions (grade I) in comparison with poorly differentiated tumors (grade III) (Table IV). In addition, a positive correlation with stage and rate of lymph node metastases and recurrences has been described $[1,5,8,47,133]$. Chung et al. [31] noted in their retrospective analysis a significantly higher incidence of lymph node metastases and tumor recurrences in patients with poorly differentiated tumors (grade III) than in those with well or moderately 
TABLE II

Incidence and site of first recurrence in relation to the highest level of positive lymph nodes

\begin{tabular}{lcccc}
\hline Site & \multicolumn{2}{l}{ Number of patients } & & References \\
\cline { 2 - 4 } & Total & $\begin{array}{l}\text { Pelvic recurrence } \\
\text { only }\end{array}$ & $\begin{array}{l}\text { Distant metastases } \\
\text { with or without } \\
\text { pelvic recurrence }\end{array}$ & \\
\hline Pelvic & 97 & $15(16)$ & $24(25)$ & 97 \\
& 19 & $3(16)$ & $3(16)$ & 30 \\
& 42 & $6(14)$ & $13(31)$ & 127 \\
& 125 & $34(27)$ & $34(27)$ & 67 \\
Para-aortic & 143 & $10(7)$ & $42(29)$ & 64 \\
and /or com- & 36 & & $27(75)$ & 138 \\
mon iliac & 23 & & $12(52)$ & 96 \\
& 23 & & $8(35)$ & 21 \\
& 31 & $13(17)$ & $17(54)$ & 136 \\
& 79 & $25(26)$ & $40(41)$ & 115 \\
\hline
\end{tabular}

a Figures in parenthesis denote percentages.

differentiated lesions (grade I-II), namely $53 \%$ versus $17 \%$ and $20 \%$ versus $6 \%$, respectively.

There is no consensus concerning the significance of cell type. Martzloff proposed classification into keratinizing, non-keratinizing, large cell and parvocellular carcinomas. According to Wentz and Reagan [31] and Van Nagell et al. [93,95] parvocellular carcinomas are regarded as prognostically unfavourable. Pejovic et al. [103], Fuller et al. [47] and Kortmeier [73] described a better prognosis for patients with squamous cell carcinoma than for patients with adenocarcinoma. Others

\section{TABLE III}

Five-year survival rate of patients in stage I B and/or II A (FIGO), positive versus negative pelvic lymph nodes

\begin{tabular}{llclll}
\hline Authors & $\begin{array}{l}\text { Total No. } \\
\text { of } \\
\text { patients }\end{array}$ & $\begin{array}{l}\text { No. with } \\
\text { negative } \\
\text { nodes }\end{array}$ & $\begin{array}{l}\text { \% 5-year } \\
\text { survival }\end{array}$ & $\begin{array}{l}\text { No. with } \\
\text { positive } \\
\text { nodes }\end{array}$ & $\begin{array}{l}\text { \% 5-year } \\
\text { survival }\end{array}$ \\
\hline Liu and Meigs, 1955 [80] & 116 & 95 & 82.0 & 21 & 38.0 \\
Brunschwig, 1960 [19] & 138 & 116 & 88.0 & 22 & 50.0 \\
Christensen et al., 1964 [29] & 167 & 139 & 92.0 & 28 & 39.3 \\
Brunschwig and Barber, 1966 [20] & 273 & 235 & 83.4 & 38 & 50.0 \\
Newton, 1975 [97] & 58 & 53 & 91.3 & 5 & 40.0 \\
Morley and Seski, 1976 [90] & 143 & 125 & 96.0 & 18 & 55.6 \\
Boyce et al., 1981 [16] & 139 & 119 & 91.0 & 20 & 62.0 \\
Ketting et al., 1981 [70] & 185 & 166 & 91.4 & 19 & 42.1 \\
Baltzer et al., 1982 [5] & 718 & - & 88.4 & - & 54.0 \\
Timmer, 1982 [127] & 193 & 151 & 94.0 & 42 & 37.0 \\
Ireland et al., 1985 [66] & 48 & 34 & 91.1 & 14 & 50.0 \\
\hline
\end{tabular}


TABLE IV

Five-year survival rate in relation to cell differentiation grade in stage I B and/or II A (FIGO)

\begin{tabular}{|c|c|c|c|c|c|c|}
\hline \multirow{3}{*}{$\begin{array}{l}\text { Differen- } \\
\text { tiation } \\
\text { grade }\end{array}$} & \multicolumn{6}{|c|}{ References } \\
\hline & \multicolumn{2}{|l|}{5} & \multicolumn{2}{|l|}{8} & \multicolumn{2}{|l|}{66} \\
\hline & $\begin{array}{l}\text { No. of } \\
\text { patients }\end{array}$ & $\begin{array}{l}\text { \% 5-year } \\
\text { survival }\end{array}$ & $\begin{array}{l}\text { No. of } \\
\text { patients }\end{array}$ & $\begin{array}{l}\text { \% 5-year } \\
\text { survival }\end{array}$ & $\begin{array}{l}\text { No. of } \\
\text { patients }\end{array}$ & $\begin{array}{l}\text { \% 5-year } \\
\text { survival }\end{array}$ \\
\hline I & 119 & 85 & 19 & 84 & 21 & 95 \\
\hline II & 407 & 80 & 18 & 78 & 6 & 83 \\
\hline III & 192 & 72 & 14 & 50 & 18 & 39 \\
\hline
\end{tabular}

$[7,13,16,30,98]$, however, found no cell-type dependent differences in prognosis. Swan et al. [124] found a better survival rate with large non-keratinizing carcinomas compared with parvocellular carcinomas after radiotherapy, but not after surgical treatment, suggesting that parvocellular carcinomas are less radiosensitive.

In summary, it is still doubtful whether cell type is of prognostic significance.

\section{Tumor size}

The prognostic significance of tumor size has been pointed out by several authors. Although different criteria concerning tumor size have been used in the literature, it might be concluded that increasing tumor size is associated with an increased incidence of lymph node metastases, recurrences and decreased 5-year survival (Table V).

\section{TABLE V}

Incidence of lymph node metastasis, recurrence and five-year survival rate in relation to tumor size in stage I B and/or II A (FIGO)

\begin{tabular}{lllllll}
\hline $\begin{array}{l}\text { Total No. of } \\
\text { patients }\end{array}$ & $\begin{array}{l}\text { Tumor } \\
\text { size }\end{array}$ & $\begin{array}{l}\text { No. of } \\
\text { patients }\end{array}$ & $\begin{array}{l}\text { \% nodes } \\
\text { positive }\end{array}$ & $\begin{array}{l}\text { \% recur- } \\
\text { rences }\end{array}$ & $\begin{array}{l}\text { \% 5-year } \\
\text { survival rate }\end{array}$ & References \\
\hline 82 & $<2 \mathrm{~cm}$ & 46 & 9 & - & 91 & 93 \\
& $\geqslant 2 \mathrm{~cm}$ & 36 & 31 & - & 69 & \\
135 & $<2 \mathrm{~cm}$ & 85 & 6 & 5 & - & 95 \\
& $\geqslant 2 \mathrm{~cm}$ & 50 & 18 & 24 & - & \\
48 & $<3 \mathrm{~cm}$ & 35 & 20 & - & - & 66 \\
& $\geqslant 3 \mathrm{~cm}$ & 13 & 40 & - & - & \\
123 & $<3 \mathrm{~cm}$ & 74 & - & - & 90 & 110 \\
& $\geqslant 3 \mathrm{~cm}$ & 49 & - & - & 65 & \\
98 & $<4 \mathrm{~cm}$ & 83 & 16 & 5 & $92^{\mathrm{a}}$ & 30 \\
& $\geqslant 4 \mathrm{~cm}$ & 15 & 80 & 80 & $47^{\mathrm{a}}$ & \\
122 & $<4 \mathrm{~cm}$ & 103 & - & 10 & - & 31 \\
& $\geqslant 4 \mathrm{~cm}$ & 19 & - & 58 & - & \\
\hline
\end{tabular}

a Two-year survival rate. 
Unfortunately, data on methods of tumor measurement have rarely been given in the literature. Most authors measured tumor size by clinical examination at the time of pre-therapeutic staging. Only a few reports gave details on tumor measurement by standardized histological work-up of the removed uterus and parametria $[4,5,18,88]$. The latter procedure is more accurate, but only possible when surgery is the primary treatment. Baltzer et al. [4,5], for instance, measured the tumor volume of the removed specimen very accurately. In a study of 595 patients they found $17 \%$ lymph node metastases when tumor volume was less than $6500 \mathrm{~nm}$ and $46 \%$ when tumor volume was more than $6500 \mathrm{~nm}$. They also found a significantly reduced 5 -year survival rate with increasing tumor volume. Whereas the 5-year survival rate of these patients with a tumor volume of $500-1500 \mathrm{~mm}^{3}$ was $84.2 \%$, the 5-year survival rate fell to $75 \%$ with a tumor volume of $6500-10000 \mathrm{~mm}^{3}$ and to $59.5 \%$ with a volume over $20000 \mathrm{~mm}^{3}$.

\section{Parametrial extension}

Although parametria appeared to be tumor-free at the time of pretherapeutic staging (FIGO), in some cases parametrial extension was found after histologic examination of the surgical specimen.

Involvement of the parametrial tissue significantly influences the results of treatment. Reported incidences of parametrial extension in early stages varied between $7 \%$ and $16.8 \%[13,60,64]$. There is a good correlation between parametrial extension and the incidence of lymph node metastases and recurrence $[13,16,60,64,82,98]$. A significant difference in 5-year survival rate has been described between patients with and without parametrial extension (Table VI).

\section{Lymph and blood vessel invasion}

Because it is difficult to distinguish between tumor invasion into lymph and blood vessels, reports in the literature are rare and great variation in incidence $(21-50 \%)$ has been reported $[43,119]$.

Positive correlations with incidence of lymph node metastases and recurrences have been reported in the literature $[5,16,25,30,44,94,95]$. There is also a vast range in 5-year survival rates of patients with lymph-blood vessel invasion (Table VII). Some authors have evaluated these factors separately, and found incidences of lymphangiosis carcinomatosa of $39-57 \%$ and incidences of blood vessel invasion of $2-29 \%[5,25,43,44,52]$. Survival was especially poor when blood vessels were invaded; 5-year survival rate was 21-50\% (Table VIII).

\section{TABLE VI}

Five-year survival rate in relation to parametrial extension (PE) in stage I B and/or II A (FIGO)

\begin{tabular}{llllll}
\hline $\begin{array}{l}\text { Total No. of } \\
\text { patients }\end{array}$ & $\begin{array}{l}\text { No. of } \\
\text { patients - PE }\end{array}$ & $\begin{array}{l}\text { \% 5-year } \\
\text { survival }\end{array}$ & $\begin{array}{l}\text { No. of } \\
\text { patients + PE }\end{array}$ & $\begin{array}{l}\text { \% 5-year } \\
\text { survival }\end{array}$ & References \\
\hline 110 & 99 & 95 & 11 & 60 & 16 \\
305 & 277 & 90 & 28 & 75 & 13 \\
307 & 291 & 97 & 16 & 81 & 64 \\
\hline
\end{tabular}


TABLE VII

Five-year survival rate in relation to lymph-blood vessel invasion (LBI) in stage I B and/or II A (FIGO)

\begin{tabular}{llllll}
\hline $\begin{array}{l}\text { Total No. of } \\
\text { patients }\end{array}$ & $\begin{array}{l}\text { No. of } \\
\text { patients - LBI }\end{array}$ & $\begin{array}{l}\text { \% 5-year } \\
\text { survival }\end{array}$ & $\begin{array}{l}\text { No. of } \\
\text { patients + LBI }\end{array}$ & $\begin{array}{l}\text { \% 5-year } \\
\text { survival }\end{array}$ & References \\
\hline 66 & 37 & 65 & 29 & 21 & 43 \\
68 & 48 & 79 & 20 & 50 & 44 \\
42 & 28 & 88 & 14 & 54 & 52 \\
84 & 51 & 90 & 33 & 60 & 6 \\
139 & 98 & 96 & 41 & 70 & 16 \\
718 & 310 & 90 & 408 & 68 & 5 \\
\hline
\end{tabular}

\section{TABLE VIII}

Five-year survival rate in relation to blood vessel invasion (BI) in stage I B and/or II A (FIGO)

\begin{tabular}{llllll}
\hline $\begin{array}{l}\text { Total No. of } \\
\text { Patients }\end{array}$ & $\begin{array}{l}\text { No. of } \\
\text { patients - BI }\end{array}$ & $\begin{array}{l}\text { \% 5-year } \\
\text { survival }\end{array}$ & $\begin{array}{l}\text { No. of } \\
\text { patients + B1 }\end{array}$ & $\begin{array}{l}\text { \%5-year } \\
\text { survival }\end{array}$ & References \\
\hline 66 & 37 & 65 & 29 & 21 & 43 \\
68 & 48 & 79 & 20 & 50 & 44 \\
718 & 648 & 83 & 69 & 30 & 5 \\
\hline
\end{tabular}

\section{Cervical invasion}

Chung et al. [30] were one of the first to describe the importance of cervical invasion in prognosis and noted a significantly increased frequency of positive lymph nodes, recurrences and reduced 2-year survival rates when depth of cervical

\section{TABLE IX}

Incidence of lymph node metastasis, recurrence and 5-year survival rates in relation to depth of cervical invasion in stage I B and/or II A (FIGO)

\begin{tabular}{llcllll}
\hline $\begin{array}{l}\text { Total No. of } \\
\text { patients }\end{array}$ & $\begin{array}{l}\text { Depth of cervi- } \\
\text { cal invasion }\end{array}$ & $\begin{array}{l}\text { No. of } \\
\text { patients }\end{array}$ & $\begin{array}{l}\text { \% node } \\
\text { positive }\end{array}$ & $\begin{array}{l}\text { \% recur- } \\
\text { rences }\end{array}$ & $\begin{array}{l}\text { \% 5-year } \\
\text { survival }\end{array}$ & References \\
\hline 684 & $<10 \mathrm{~mm}$ & - & 11 & - & - & 4 \\
& $>10 \mathrm{~mm}$ & - & 27 & - & - & \\
51 & $<10 \mathrm{~mm}$ & 43 & 14 & - & 79 & 8 \\
& $>10 \mathrm{~mm}$ & 8 & 50 & - & 50 & \\
136 & $<10 \mathrm{~mm}$ & 89 & - & 5 & 96 & 16 \\
& $>10 \mathrm{~mm}$ & 47 & - & 34 & 70 & \\
150 & $<50 \%$ & 129 & - & - & 88 & 133 \\
& $>50 \%$ & 21 & - & - & 80 & \\
85 & $<50 \%$ & 70 & 13 & 4 & $93^{\mathrm{a}}$ & 30 \\
& $>50 \%$ & 15 & 40 & 40 & $67^{\mathrm{a}}$ & \\
\hline
\end{tabular}

${ }^{a}$ Two-year survival rate. 
invasion was more than $70 \%$. Many other authors, although using different selection criteria, also reported good correlation between the depth of cervical invasion and the incidence of lymph node metastasis, recurrence and 5-year survival rate (Table IX).

Only Underwood et al. [133] found no significant differences in survival rates between cervical invasion of greater or less than $50 \%$.

Other possible prognostic factors

Age and hormonal status have been mentioned as prognostic factors, although reported conclusions were not unanimous $[40,88,103,123]$. According to Boyce et al. [16], Noguchi et al. [98], Rotman et al. [119] and Perez et al. [105] patients with tumor extension to the corpus uteri or vagina have a high risk of treatment failure.

Lymphatic cell infiltration in stroma has been found to be of prognostic importance by some authors [5,49,4], although Noguchi et al. [98] could not demonstrate a relationship between survival and stromal infiltration. Baltzer et al. [5] noted that the morphology of the tumor was of importance with regard to prognosis. Various reports have suggested that endocervical tumors are related to an increased rate of local recurrence and consequently have poorer survival rates $[1,47,48,95,101,119]$.

In 1947 Graham showed a correlation between tumor regression after radiotherapy and treatment outcome. This observation has been confirmed, suggesting that there are differences in the radiosensitivity of cervical carcinomas $[52,58,88]$.

\section{Discussion}

\section{The main prognostic factors}

Various factors related to prognosis have been studied, but the question of which prognostic factor should be regarded as the most important has not been answered.

Reviewing mainly retrospective data in the literature, lymph node metastases, differentiation grade, tumor size, parametrial extension, lymph-blood vessel invasion and cervical invasion appear to allow prediction of survival. The relative importance of any single factor is difficult to determine without a multivariate analysis, because most of the prognostic factors are interrelated. A combination of certain factors apparently has a worse prognosis than those factors separately. Bleker et al. [13] and Inoue [64], for example, found a significantly lower survival rate in patients with parametrial extension and lymph node metastases together when compared to patients in whom only one of these factors was present. The first author noted a 5-year survival rate of 50\% if parametrial extension and lymph nodes were positive. These figures increased to $62.1 \%$ if only positive lymph nodes were found, and to $75 \%$ if only parametrial extension was diagnosed. The survival rate was $90.3 \%$ when none of these factors was present. The second author reported that parametrial invasion and lymph node involvement combined reveals a 5-year survival rate of $42.5 \%$, rising to $73.3 \%$ in cases of positive lymph nodes only, and to $69.6 \%$ in cases with parametrial invasion only. Patients without these factors had a survival rate of $97.3 \%$. Fuller et al. [47] described the added detrimental effect of 
increased tumor size, lymph-blood vessel invasion and deep cervical invasion on the prognosis of patients with lymph node metastases.

This survey suggests that the FIGO classification, which is based on clinical examination, is inaccurate for subdividing groups of patients for therapy and prognosis. Patient selection according to the tumor characteristics, as discussed in this article, is more accurate, but is possible only by careful standardized examination of the surgical specimen after surgical treatment. Modifications of standard treatment on the basis of pathologic parameters have been suggested by several other authors $[5,16,47,49,95,119,139]$.

\section{Site of recurrence in relation to prognostic factors}

Besides prognostic considerations, the site of recurrence is also important with regard to alterations in conventional treatment. Not only the high risk of recurrence but also knowledge of the site of recurrence is essential for interpretation of the need for additional therapy. The high incidence of distant recurrence and the relatively low incidence of pelvic recurrence in patients treated with surgery, radiotherapy or a combination of these methods indicates that locoregional therapy is insufficient. It suggests that patients could benefit more from systemic therapy.

Analysis of recurrence sites in relation to prognostic factors has rarely been performed, although some retrospective analyses have been reported. It has already been pointed out in this review that pelvic lymph node metastasis is associated with distant recurrence, with or without pelvic recurrences, in 16-31\% of patients. Incidences of only pelvic recurrences in this group range from $7 \%$ to $27 \%$. The number and the degree of node involvement seem to increase the risk of distant metastases. Large positive pelvic nodes $(>20 \mathrm{~mm}$ ) were highly correlated with more than three positive pelvic nodes according to Inoue et al. [65]. Chung et al. [30] found an incidence of $70 \%$ distant metastasis with grossly positive pelvic nodes.

Although blood vessel invasion is associated with a high recurrence rate (up to $70 \%$ ) and a poor prognosis, there are no exact figures concerning the recurrence sites. With combined lymph-blood vessel invasion, 23-25\% distant recurrences and 13-20\% pelvic recurrences have been reported $[30,94]$. These data allow no conclusions concerning the risk of distant recurrence in relation to invasion of blood vessels alone.

Patients with tumors larger than $4 \mathrm{~cm}$ had 14-40\% incidence of distant recurrences and 9-40\% incidence of pelvic recurrences [30,48].

Incidences of distant and pelvic recurrences of $20 \%$ and $25 \%$ respectively have been reported in relation to differentiation grade III [31]. These findings indicate that large tumors $(>4 \mathrm{~cm}$ ) and poor differentiation (grade III) increase the risk of pelvic recurrences as much as for distant recurrences.

Chung et al. [30] found a higher incidence of pelvic recurrences than of distant recurrences, $27 \%$ versus $13 \%$, when cervical invasion was more than $70 \%$.

In summary, there are some indications that patients with para-aortic and multiple $(>3)$ pelvic lymph node metastases have higher incidences of distant recurrences than of pelvic recurrences. Unfortunately there are too few data to indicate the recurrence sites of patients with blood vessel invasion, differentiation 
grade III, large tumors and deep cervical invasion, but the incidence of recurrence at both pelvic and distant sites is high. However, so far there have been no studies in the literature that prove that this hypothesis is correct.

\section{The impact of treatment}

One of the questions to be answered is whether there are possible therapy modifications for improvement of survival of patients with one or more poor prognostic features. The efficacy of the current radiotherapeutic treatment strategies is not well defined for every subgroup.

A study by Lagasse et al. [74] suggested that radiotherapy with a dose of $5000 \mathrm{rad}$ could sterilize undetected pelvic tumor residues in operated stage I B and II A patients. They found in a prospective randomized analysis of 118 stage I B patients an apparent decrease (from $22.4 \%$ to $11.7 \%$ ) in the incidence of observed pelvic node involvement after radiation therapy. According to these findings postoperative radiotherapy might benefit high-risk patients also. Postoperative pelvic radiation for patients with lymph node metastases and parametrial extension of lymph-blood vessel invasion has been investigated in several studies. Some authors reported a slightly improved survival rate $[41,53,68,86]$, but the majority $[13,16,30,47,60,91$, 120,139 ] did not find a better survival rate with this additional treatment. Unfortunately all these studies were retrospective and used non-randomized analysis. However, according to these studies it might be concluded that the effectiveness of postoperative pelvic radiotherapy is still doubtful. A possible explanation for this lack of response is that the presence of these prognostic factors may not represent the anatomical spread of disease but rather may be associated with undetected extrapelvic metastases. This hypothesis is supported by some studies $[8,47,60,127]$. Postoperative radiated patients had fewer pelvic recurrences but more extrapelvic recurrences in comparison with non-radiated patients. Extensive randomized prospective studiés are still necessary to evaluate this additional treatment.

The value of applying para-aortic radiation in early-stage carcinoma of the cervix with para-aortic lymph node metastases is still unknown. Extended-field radiation has been used more in advanced stages, because in these stages there is a relatively high incidence of para-aortic node involvement, $17-35 \%[3,11,37,63,76,131,136]$. However, there also seems to be a high incidence of para-aortic disease in high-risk patients in early stages $[63,75,136]$. Early-stage patients with tumors of more than 4 $\mathrm{cm}$, blood vessel invasion, or para-aortic or multiple $(>3)$ pelvic lymph node metastases appeared to have survival rates which are comparable with those in advanced stages. This suggests the need for investigation of the effectiveness of adjuvant treatment in this patient group. In advanced stages some patients with biopsy-proven para-aortic disease have been cured with extended-field radiotherapy. Five-year survival rates of $9.6-29 \%$ have been reported. The majority still died from recurrent disease. Analysis of sites of recurrences in patients with positive para-aortic nodes suggests that many develop para-aortic and distant metastases simultaneously (Table II). In addition, extended-field radiation is associated with a high risk of severe complications $[3,11,27,37,115]$. In reports of systemic therapy, cis-platinum is the best-documented agent showing activity. Response rates with this cytotoxic 
agent in advanced recurrent carcinomas vary between 30 and $70 \%[22,23,34,45,118$, $122,125,126]$, with preference for the lower response rates. This variation in response rates is due to different risk factors in patient populations and different criteria in determining the response. Combination chemotherapy of cis-platinum and other active drugs results in comparable response rates. Theoretically, in patients with occult distant micro-metastases it may be possible to eliminate micro-metastases by chemotherapy alone.

\section{Conclusions}

The current knowledge of prognostic factors and sites of recurrence is based mainly on retrospective studies. The literature indicates that lymph node metastasis, differentiation grade, tumor size, parametrial extension, lymph-blood vessel invasion and cervical invasion seem to be of prognostic importance in stage I B and II A carcinoma. The relative importance of any single factor is difficult to determine without a multivariate analysis because most of the prognostic reactors are interrelated.

According to the findings mentioned before, it appears that the current treatment is insufficient to improve survival of high-risk patients. Improvement in survival with para-aortic or multiple $(>3)$ pelvic lymph node metastases can mainly be established by the development of an effective systemic treatment. Patients with blood vessel invasion, tumors of more than $4 \mathrm{~cm}$ diameter, differentiation grade III, or cervical invasion of more than $70 \%$ could also benefit from systemic treatment. However, better pelvic controls seems to be important as well with these factors.

Refined radiotherapeutic treatment is necessary to improve control at the pelvic site. Recently developed modalities such as radiation sensitizers and protectors, hyperthermia or high LET particles seems promising [17,106,113,119].

A further improvement in treatment of patients with early stages of cervical cancer and at risk for distant metastasis may be provided by adjuvant chemotherapy to eliminate those micrometastases outside the pelvis.

The findings concerning prognostic variables indicate that the FIGO classification alone, which is based on clinical examination, is an inaccurate basis on which to subdivide patients with regard to treatment and prognosis. It seems useful to define subgroups of patients according to the characteristics of the tumor defined after surgical treatment and accurate pathological examination of the surgical specimen.

\section{References}

1 Abdulhayoglu G, Rich WM, Reynolds J, et al. Selective radiation therapy in stage I B uterine cervical carcinoma following radical pelvic surgery. Gynecol Oncol 1980;10:84-92.

2 Allen HH, Nisker JA, Anderson RJ. Primary surgical treatment in one hundred ninety-five cases of stage I B carcinoma of the cervic. Am J Obstet Gynecol 1982;143:581-584.

3 Ballon SC, Berman ML, Lagasse LD, et al. Survival after extraperitoneal pelvic and paraaortic lymphadenectomy and radiation therapy in cervical carcinoma. Obstet Gynecol 1981;57:90-95.

4 Baltzerr J, Kopcke W. Tumor size and lymph node metastases in squamous cell carcinoma of the uterine cervix. Arch Gynecol 1979;227:271-278. 
5 Baltzerr J, Lohe KJ, Kopcke W, et al. Histological criteria for the prognosis in patients with operated cell carcinoma of the cervix. Gynecol Oncol 1982;13:184-194.

6 Barber HRK, Sommers SC, Rotterdam H, et al. Vascular invasion as a prognostic factor in stage I B cancer of the cervix. Obstet Gynecol 1978;52:343-348.

7 Beechan KB, Halvorsen T, Kolbenstedt A. Histologic classification, lymph node metastases and patient survival in stage I B cervical carcinoma. Gynecol Oncol 1978;6:95-105.

8 Berek SJ, Hacker NF, Fu YS, et al. Adenocarcinoma of the uterine cervix: Histologic variables associated lymph node metastases and survival. Obstet Gynecol 1985;65:46-51.

9 Berkowitz RS, Leavitt T, Knapp RC. Ultra-sound-directed percutaneous aspiration biopsy of periaortic lymp nodes in recurrence of cervical carcinoma. Am J Obstet Gynecol 1978;131:906-908.

10 Berman ML, Lagasse LD, Watring WG, et al. The operative evaluation of patients with cervical carcinoma by an extraperitoneal approach. Obstet Gynecol 1977;50:658-664.

11 Berman ML, Keys H, Creesman W, et al. Survival and patterns of recurrence in cervical cancer metastases to periaortic lymph nodes. Gynecol Oncol 1984;19:8-16.

12 Blake PR, Lambert HE, MacGregor WG, et al. Surgery following chemotherapy and radiotherapy for advanced carcinoma of the cervix. Gynecol Oncol 1984;19:198-203.

13 Bleker DP, Ketting W, van Wayjen-Eecen B, et al. The significance of microscopic involvement of the parametrium and/or pelvic lymph nodes in cervical cancer stage I B and II A. Gynecol Oncol 1983;16:56-62.

14 Boice CR, Freedman RS, Herson J, et al. Bleomycin and Mytomycin-C (BLM-M) in recurrent squamous uterine cervical cancer. Cancer 1982;49:2242-2245.

15 Bonfiglio FA, MacIntosh PK, Patten Jr SF, et al. Fine needle aspiration cytopathology of retroperitoneal lymph nodes in the evaluation of metastatic disease. Acta Cytol 1979;23:126-130.

16 Boyce J, Fruchter RG, Nicastri AD, et al. Prognostic factors in stage I carcinoma of the cervix. Gynecol Oncol 1981;12:154-165.

17 Brady LW, Phillips FL, Wassermann TH. The potential for radiosensitizers and radiation protectors combined with radiation therapy in gynecologic cancer. Cancer 1981;48:650-657.

18 Braunig G, Lohe K, Baltzer J, et al. Tumormetrische Untersuchungen beim Cervixcarcinom. Arch Gynakol 1973;214:105-107.

19 Brunschwig A. Surgical treatment of stage I cancer of the cervix. Cancer 1960;13:34-36.

20 Brunschwig A, Barber HRK. Surgical treatment of carcinoma of the cervix. Obstet Gynecol 1966;27:21-29.

21 Buchsbaum HJ. Extrapelvic lymph node metastases in cervical carcinoma. Am J Obstet Gynecol 1979;133:814-819.

22 Carlson JA, Freedman RS, Wallace S, et al. Intraarterial cis-platinum in the management of squamous cell carcinoma of the uterine cervix. Gynecol Oncol 1981;12:92-98.

23 Carlson JA, Day TG, Allegra JC, et al. Methyl-CCNU, doxorubicin and cis-diamminedichloroplatinum 2 in the management of recurrent and metastatic squamous carcinoma of the cervix. Cancer 1984;54:211-214.

24 Cherry C.P, Ghucksmann A, Dearing R, et al. Ohservations on lymph node involvement in carcinoma of the cervix. J Obstet Gynaecol Br Emp 1953;60:368-372.

25 Cherry CP, Glucksmann AA. Lymphatic embolism and lymph node metastasis in cancers of vulva and uterine cervix. Cancer 1955;8:564-567.

26 Cheung AYC. Extended field irradiation for invasive carcinoma of the cervix. Gynecol Oncol 1980;9:280-291.

27 Chism SE, Park RC, Keys HM. Prospects for paraaortic irradiation in treatment of cancer of the cervix. Cancer 1975;35:1505-1509.

28 Choo YC. Chemotherapy in advanced and recurrent cervical carcinoma. Int J. Gynecol Obstet 1982;20:417-423.

29 Christensen A, Lange P, Nielsen E. Surgery and radiotherapy for invasive cancer of the cervix. Acta Obstet Gynecol Scand 1964;43(suppl. 2):59-87.

30 Chung CK, Nahhas WA, Strijker JA, et al. Analysis of factors contributing to treatment failures in stage I B and II A carcinoma of the cervix. Am J Obstet Gynecol 1980;138:550-556.

31 Chung CK, Strijker JA, Ward SP, et al. Histologic grade and prognosis of carcinoma of the cervix. Obstet Gynecol 1981;57:636-642. 
32 Churches CK, Kurrle GR, Johnson B. Treatment of carcinoma of the cervix by combination of irradiation and operation. Am J Obstet Gynecol 1974;118:1033-1040.

33 Cohen CJ, Deppe G, Yannopoulos K, et al. Chemosensitivity testing with cis-platinum (2) diamminedichloride. 1. A new concept in the treatment of carcinoma of the cervix. Gynecol Oncol 1982;13:1-9.

34 Daghestani AN, Hakes TH, Lynch G, et al. Cervix carcinoma: Treatment with combination cis-platin and bleomycin. Gynecol Oncol 1983;16:334-339.

35 Day Jr. TG, Wharton JT, Gottlieb JA, et al. Chemotherapy for squamous carcinoma of the cervix: doxorubicin-methyl CCNU. Am J Obstet Gynecol 1978;132:545-548.

36 Delgado G. Stage I B squamous cancer of the cervix: The choice of treatment. Obstet Gynecol Surv 1978;33:174-182.

37 Delgado G, Caglar H, Walker P. Survival and complications in cervical cancer treated by pelvic and extended field radiation after paraaortic lymphadenectomy. Roentgenology 1978;130:141-143.

38 Deppe G, Cohen CJ, Yannopoulos K, et al. Chemosensitivity testing with cis-platinum (2) diamminedichloride. 2. Preliminary experience in the treatment of carcinoma of the cervix. Gynecol Oncol 1982;13:10-18.

39 Di Saia PJ. Surgical aspects of cervical carcinoma. Cancer 1981;48:548-559.

40 Dodds JR, Latour JPA. Relationship of age to survival rate in carcinoma of the cervix. Am J Obstet Gynecol 1961;82:33-36.

41 Einhorn N, Bygdeman M, Sjoberg B. Combination radiation and surgical treatment for carcinoma of the uterine cervix. Cancer 1980;45:720-723.

42 Fletcher GH, Ruthledge FN. Overall results in radiotherapy for carcinoma of the cervix. Clin Obstet Gynecol 1967;10:958-961.

43 Friedell GH, Parsons L. Blood vessel invasion in cancer of the cervix. Cancer 1962;15:1269-1272.

44 Friedell GH, Steiner G, Kistner RW. Prognostic value of blood vessel invasion in cervical cancer. Obstet Gynecol 1967;29:855-857.

45 Friedlander ML, Kaye SB, Sullivan A, et al. Cervical carcinoma: A drug-responsive tumor experience with cisplatin, vinblastin and bleomycin therapy. Gynecol Oncol 1983;16:275-281.

46 Friedlander ML, Atkinson K, Coppleson JVM, et al. The integration of chemotherapy into management of locally advanced cervical cancer: A pilot study. Gynecol Oncol 1984;19:1-7.

47 Fuller AF, Elliott N, Rosloff C, et al. Lymph node metastases from carcinoma of the cervix, stages I B and II A: implications for prognosis and treatment. Gynecol Oncol 1982;13:165-174.

48 Gallion H, Nagell JR van, Donaldson ES, et al. Treatment of bulky, barrel-shaped stage I B carcinoma of the uterine cervix with radiation alone or in combination with surgery. Gynecol Oncol 1984;17:258-262.

49 Gauthier P, Gore I, Shingleton HM, et al. Identification of histopathology risk groups in early stage cervical cancer. Gynecol Oncol 1984;17:252-256.

50 Gothlin JH. Post-lymphographic percutaneous fine needle biopsy of lymph nodes guided by fluoroscopy. Radiology 1976;120:205-207.

51 Graham I, Graham R, Hirahayashi K. Recurrent cancer of the cervix uteri. Surgery Gynecol and Obstet 1968;126:700-704.

52 Gusberg SB, Herman GG. Radiosensitivity and virulence factors in cervical cancer. Am J Obstet Gynecol 1968;100:627-639.

53 Guttmann R. Significance of postoperative irradiation in carcinoma of the cervix: a ten year survey. Am J Rontgenol 1970;108:102-108.

54 Guthrie D, Way S. The use of adriamycin and methotrexate in carcinoma of the cervix. The development of a safe effective regimen. Obstet Gynecol 1978;52:349-354.

55 Hall DJ, Diasio R, Goplerud DR. Cisplatinum in gynecologic cancer. 2. Squamous cell carcinoma of the cervix. Am J Obstet Gynecol 1982;141:305-308.

56 Hall DJ, Diasio R, Goplerud DR. Cisplatinum in gynaecologic cancer. 3. Toxicity. Am J Obstet Gynecol 1982;141:309-312.

57 Hannigan EV, Dillard EA, Dinh TV. Bleomycin, vincristine and methotrexate with citrovorum factor rescue in the treatment of advanced squamous cell carcinoma of the cervix. Gynecol Oncol 1984;19:57-59.

58 Hardt N, Nagell JR van, Hanson M, et al. Radiation-induced tumor regression as a prognostic factor in patients with invasive cervical cancer. Cancer 1982;49:35-39. 
59 Heller PB, Lee RB, Leman MH, et al. Lymph node positivity in cervical cancer. Gynecol Oncol 1981;12:328-335.

60 Hogan WM, Littman P, Griner L, et al. Results of radiation therapy given after radical hysterectomy. Cancer 1982;49:1278-1285.

61 Hoskins WJ, Ford JH, Lutz MH, et al. Radical hysterectomy and pelvic lymphadenectomy for management of early invasive cancer of the cervix. Gynecol Oncol 1976;4:278-290.

$62 \mathrm{Hsu}$ CT, Liu IS. Surgical treatment of cancer of the uterine cervix. Am J Obstet Gynecol 1966;95:706-713.

63 Hughes RR, Brewington KC, Hanjani P, et al. Extended field irradiation for cervical cancer based on surgical staging. Gynecol Oncol 1980;9:153-161.

64 Inoue T, Okumura M. Prognostic significance of parametrial extension in patients with cervical carcinoma stages I B, II A and II B. Cancer 1984;54:1714-1719.

65 Inoue $\mathrm{T}$, Chihara $\mathrm{T}$, Morita $\mathrm{K}$. The prognostic significance of the size of the largest node in metastatic carcinoma from the uterine cervix. Gynecol Oncol 1984;19:187-193.

66 Ireland D, Hardiman P, Monaghan JH. Adenocarcinoma of the uterine cervix: A study of 73 cases. Obstet Gynecol 1985;65:82-85.

67 Iversen T, Kjorstad KE, Martimbeau PW. Treatment results in carcinoma of the cervix state I B in a total population. Gynecol Oncol 1982;14:1-5.

68 Jobson VW, Girtanner RE, Averette HE. Therapy and survival of early invasive carcinoma of the cervix uteri with metastases to the pelvic nodes. Surg Gynecol Obstet 1980;151:27-29.

69 Johnson DW, Cox RS, Hower AE, et al. The use of paraaortic radiation therapy based on lymphangiogram interpretation in uterine cervical carcinoma. Gynecol Oncol 1983;16:326-333.

70 Ketting BW. Surgical treatment of invasive carcinoma of the uterine cervix. Dissertatie, Amsterdam, 1981.

71 Kjorstadt KE, Kolbenstedt A, Strickert T. The value of complete lymphadenectomy in radical treatment of cancer of the cervix. Cancer 1984;54:2215-2219.

72 Kolstadt P. Gynecologic oncology: present status and future aspects. Am J Obstet Gynecol 1973;115:597-605.

73 Kottmeier HL. (ed.). Anual report on the results of treatment in gynecological cancer. Vol. 17, p. 58-111; Stockholm, 1979.

74 Lagasse LD, Smith ML, Moore JG, et al. The effect of radiation therapy on pelvic lymph node involvement in stage I carcinoma of the cervix. Am J Obstet Gynecol 1974;119:328-332.

75 Lagasse LD, Ballon SC, Berman ML, et al. Pretreatment lymphangiography and operative evaluation in carcinuma of the cervix. Am J Obstet Gynecol 1979;134:219-224.

76 Lagasse LD, Creasman WT, Shingleton HM, et al. Results and complications of operative staging in cervical cancer: experience of the gynecologic oncology group. Gynecol Oncol 1980;9:90-98.

77 Lele SB, Piver MS, Barlow JJ. Cyclophosphamide, adriamycin and platinum chemotherapy in treatment of advanced recurrent cervical carcinoma. Gynecol Oncol 1983;16:15-18.

78 Lepanto P, Littman P, Mikuta J, et al. Treatment of paraaortic nodes in carcinoma of the cervix. Cancer 1975;35:1510-1513.

79 Lerner HM, Jones HW, Hill EC. Radical surgery for the treatment of early invasive cervical carcinoma (stage I B): Review of 15 years experience. Obstet Gynecol 1980;56:413-418.

80 Liu W, Meigs JV. Radical hysterectomy and pelvic lymphadenectomy. Am J Obstet Gynecol 1955;69:1-32.

81 Lorrens AS. Chemotherapy of squamous cell carcinoma of the cervix. Obstet Gynecol 1980;55:373-375.

82 Lucraft HH. Radiotherapy following primary surgery for carcinoma of the uterine cervix. Clin Radiol 1981;32:347-353.

83 MacIntosh PK, THomson KR, Barbaric ZL. Percutaneous transperitoneal lymph node biopsy as a means of improving lymphographic diagnosis. Radiol 1979;131:647-649.

84 Malkasian Jr D, Decker JG, Green SJ, et al. Treatment of recurrent and metastatic carcinoma of the cervix: Comparison of doxorubicin with a combination of vincristine and 5-fluorouracil. Gynecol Oncol 1983;11:235-239.

85 Martimbeau PW, Kjorstedt KE, Kolstadt P. Stage I B carcinoma of the cervix, the Norwegian Radium Hospital, 1968-1979: Results of treatment and major complications. Am J Obstet Gynecol 1978;131:389-392. 
86 Marziale P, Atlantal G, Le Pera V, et al. Combined radiation and surgical treatment of stage I B, II $A$ and B carcinoma of the cervix. Gynecol Oncol 1981;11:175-183.

87 McGowan. Gynecologic Oncology. Appleton Century Croft, New York, 1978; chapters 11 and 12.

88 Mendelhall WM, Thar TL, Bova FJ, et al. Prognostic and treatment factors affecting pelvic control of stage I B and II A-B carcinoma of the intact uterine cervix treated with radiation therapy alone. Cancer 1984;53:2649-2654.

89 Mitani Y, Fujii J, Miyamura M, et al. Lymph node metastases of carcinoma of the uterine cervix. Am J Obstet Gynecol 1962;84:515-522.

90 Morley GW, Seski JC. Radical pelvic surgery versus radiation therapy for stage I carcinoma of the cervix uteri (exclusive of microinvasion). Am J Obstet Gynecol 1976;126:785-794.

91 Morrow CP. Is pelvic radiation beneficial in the postoperative management of stage I B squamous cell carcinoma of the cervix with pelvic nodes metastases treated by a radical hysterectomy and pelvic lymphoadenectomy? Gynecol Oncol 1980;10:105-110.

92 Nagell JR van, Roddick JW, Lowin DM. The staging of cervical cancer: inevitable discrepancies between clinical staging and pathologic findings. Am J Obstet Gynecol 1971;110:973 978.

93 Nagell JR van, Donaldson ES, Parker JC, et al. The prognostic significance of cell type and lesion size in patients with cervical cancer treated by radical surgery. Gynecol Oncol 1977;5:142-151.

94 Nagell JR van, Donaldson ES, Wood EG, et al. The significance of vascular invasion and lymphatic infiltration in invasive cervical cancer. Cancer 1978;41:228-234.

95 Nagell JR van, Rayburn W, Donaldson ES, et al. Therapeutic implications of patterns of recurrence in cancer of the uterine cervix. Cancer 1979;44:2354-2361.

96 Nelson JH, Macasaet MA, Bohorquez JF, et al. The incidence and significance of paraaortic lymph node metastases in invasive carcinoma of the cervix. Am J Obstet Gynecol 1974;118:749-755.

97 Newton M. Radical hysterectomy or radiotherapy for stage I cervical cancer. Am J Obstet Gynecol 1975; $123: 535-540$.

98 Noguchi H, Shiozawa K, Tsukamoto T, et al. The postoperative classification for uterine cervical cancer and its clinical evaluation. Gynecol Oncol 1983;16:219-231.

99 Nordquist SRB, Jaramillo B, Ford JH, et al. Selective therapy for early cancer of the cervix, surgically explored non-resected cases. Gynecol Oncol 1979;7:248-256.

100 Nordquist SRB, Jaramillo B, Sudarsands A, et al. Selective therapy for early cancer of the cervix, surgically non-explored cases. Gynecol Oncol 1979;7:257-263.

101 Novak ER. Gynecologic and Obstetric Pathology, 1979; Chapter 5.

102 Parker Jr RL, Welander CE, Homesly HD, et al. Use of the human tumor stem cell assay to study chemotherapy sensitivity in cancer of the cervix. Obstet Gynecol 1984;64:412-416.

103 Pejovic MH, Wolff JP, Kramar A, et al. Cure rate estimate on and long-term prognosis of uterine cervix carcinoma. Cancer 1981;47:203-206.

104 Perez CA. Irradiation alone or in combination with surgery in stage I B and II A carcinoma of the uterine cervix. Cancer 1975;35:1062-1072.

105 Perez CA, Zivnuska F, Askin F, et al. Prognostic significance of endometrial extension for primary carcinoma of the uterine cervix. Cancer 1975;35:1493-1504.

106 Perez CA, Breaux S, Askin F, et al. Radiation therapy alone in the treatment of carcinoma of the uterine cervix. I. Analysis of tumor recurrence. Cancer 1983;51:1393-1402.

107 Perkins PL, Chu AM, Josc B, et al. Posthysterectomy megavoltage irradiation in the treatment of cervical carcinoma. Gynecol Oncol 1984;17:340-348.

108 Petrilli ES, Castaldo TW, Ballon SC, et al. Bleomycin-mitomycin C therapy for advanced squamous carcinoma of the cervix. Gynecol Oncol 1980;9:292-297.

109 Pilleron JR, Durand JC, Hamelin JP. Prognosis value of node metastasis in cancer of the uterine cervix. Am J Obstet Gynecol 1974;119:485-492.

110 Piver MS, Chung CK. Prognostic significance of cervical lesion size and pelvic node metastases in cervical carcinoma. Obstet Gynecol 1975;46:507-513.

111 Piver MS, Barlow JJ. High dose irradiation to biopsy confirmed aortic node metastases from carcinoma of the uterine cervix. Cancer 1977;39:1234-1246.

112 Piver MS, Barlow JJ, Krishamsetty R. Five-year survival (with no evidence of disease) in patients with biopsy-confirmed aortic node metastasis from cervical carcinoma. Am J Obstet Gynecol 1981;139:575-578. 
113 Piver MS, Barlow JJ, Vongtama V, et al. Hydroxyurea: a radiation potentiator in carcinoma of the uterine cervix. A randomized double blind study. Am J Obstet Gynecol 1983;147:803-808.

114 Plentl AA, Friedman EA. The lymphatic system of the female genitalia, the morphologic basis for oncologic diagnosis and therapy. Saunders, Philadelphia, 1971.

115 Potish RA, Adcock L, Jones T, et al. The morbidity and utility of periaortic radiotherapy in cervical carcinoma. Gynecol Oncol 1983;15:1-9.

116 Potish RA, Twiggs L, Adcock L, et al. The utility and limitations of decision theory in the utilization of surgical staging and extended field radiotherapy in cervical cancer. Obstet Gynecol Surv 1984;39:555-562.

117 Roberts JA, Morley GW, Natale RB, et al. Combination cisplatin and dichloromethotrexate in patients with advanced or recurrent cervical cancer: a preliminary report. Gynecol Oncol 1984;19:194-197.

118 Rosenthal CJ, Khulpateea N, Boyce J, et al. Effective chemotherapy for advanced carcinoma of the cervix with bleomycin, cisplatin, vincristine and methotrexate. Cancer 1983;52:2025-2030.

119 Rotman MV, John M, Boyce J. Prognostic factors in cervical carcinoma: implications in staging and management. Cancer 1981;48:560-567.

120 Russel AH, Tong DY, Figge DC, et al. Adjuvant postoperative pelvic radiation for carcinoma of the uterine cervix: pattern of cancer recurrence in patients undergoing elective radiation following radical hysterectomy and pelvic lymphadenectomy. Int J Radiat Oncol Biol Phys 1984;10:211-220.

121 Sorbe B, Frankendal B. Combination chemotherapy in advanced carcinoma of the cervix. Cancer 1982;50:2028-2030.

122 Sorbe B, Frankendal B. Bleomycin-Adriamycin-Cisplatin combination chemotherapy in the treatment of primary advanced and recurrent cervical carcinoma. Obstet Gynecol 1984;63:167-170.

123 Stanhope CR, Smith JP, Wharton JT, et al. Carcinoma of the cervix: the effect of age on survival. Gynecol Oncol 1980;10:188-193.

124 Swan DS, Roddick JW. A clinical pathological correlation of cell type classification of cervical cancer. Am J Obstet Gynecol 1973;116:666-670.

125 Thigpen $\mathrm{T}$, Shingleton $\mathrm{H}$, Homesly $\mathrm{H}$, et al. Cisplatin in treatment of advanced or recurrent squamous cell carcinoma of the cervix. A phase 2 study of the gynecologic oncology group. Cancer 1981;48:899-903.

126 Thigpen T, Vance RB, Balducci L, et al. Chemotherapy in the management of advanced or recurrent cervical and endometrial carcinoma. Cancer 1981;48:S658-665.

127 Timmer PR. The behandeling van het cervixcarcinoom in het Academisch Ziekenhuis te Groningen van 1970-1979. Dissertatie, Groningen, 1982.

128 Townsend SR, Kurrle GR. Cancer of the cervix (stages I B, II A and II B): Treatment and results. Aust N Z J Obstet Gynecol 1980;20:224-227.

129 Trope C, Johnsson JE, Grundsell H, et al. Adriamycin-Methotrexate combination chemotherapy of advanced carcinoma of the cervix: A third look. Obstet Gynecol 1980;55:488-492.

130 Twiggs LB, Potish RA. Decision theory analysis of the enteric morbidity and surgical staging in the treatment of advanced cervical cancer. Am J Obstet Gynecol 1984;148:134-140.

131 Twiggs LB, Potish RA, George RJ. Pretreatment extraperitoneal surgical staging in primary carcinoma of the cervix uteri. Surg Gynecol Obstet 1984;158:243-250.

133 Underwood JR PB, Wilson WC, Kreutner A, et al. Radical hysterectomy: a criteriae review of twenty-two years experience. Am J Obstet Gynecol 1979;134:889-898.

134 Wasserman TH, Carter SK. The integration of chemotherapy into combined modality treatment of solid tumors. VII. Cervical cancer. Cancer Treat Rev 1977;4:25-46.

135 Webb MJ, Symmonds RE. Site of recurrence of cervical cancer after radical hysterectomy. Am J Obstet Gynecol 1980;138:813-817.

136 Welander CE, Pierce VK, Nori D, et al. Pretreatment laparotomy in carcinoma of the cervix. Gynecol Oncol 1981;12:336-347.

137 Weppelman B, Monkemeier D. The influence of prostaglandin-antagonists on radiation therapy of carcinoma of the cervix. Gynecol Oncol 1984;17:196-199.

138 Wharton GT, Jones HW, Day TG, et al. Preirradiation celiotomy and extended field irradiation for invasive carcinoma of the cervix. Obstet Gynecol 1979;49:333-340.

139 Zander J, Baltzer J, Lohe $\mathrm{KJ}$, et al. Carcinoma of the cervix: an attempt to individualize treatment. Am J Obstet Gynecol 1981;139:752-759. 